\title{
STATISTICAL THINKING PROFILE OF FIELD INDEPENDENT AND FIELD DEPENDENT SENIOR HIGH SCHOOL STUDENTS IN PROBLEM SOLVING
}

\author{
Rohmatus Tsaniyah \\ Mathematics Education, Mathematics and Natural Sciences Faculty, State University of Surabaya \\ Email : rohmatustsanivah16030174044@mhs.unesa.ac.id
}

\begin{abstract}
Statistical thinking is a mental activity that occurs from the process of identifying statistical information to the process of making decisions or drawing conclusions that are interconnected. One that can effect individual statistical thinking profiles is cognitive style. The purpose of this research is to describe the statistical thinking profile of Field Independent (FI) and Field Dependent(FD) high school student in solving problems. This research is a descriptive study with a qualitative approach. The instruments of this research are the researcher as the main instrument and cognitive style test, mathematics ability test, and interview guidelines as the supporting instruments. Research subjects are one of FI student and one of FD student with an equivalent level of high mathematical ability. The results of this study indicate differences in the profile of FI student an FD student statistical thinking. In evaluating the effectiveness of the data display, FI student can provide analytical argument about the presentation of data display that more effectively used and FD student-provide answers for the presentation of effective data displays based on what is seen from the question. In describing the results of the available problems and making conclusions from the results that have been obtained, FI-student describes the solutions in more detail accompanied by the arguments also provide conclusions related to the existing problems and FD student briefly describes the solutions and provide general conclusions and have not been linked to the existing problems. Because of the statistical ability of two subjects is different, teacher should pay attention to the statistical concepts and train students on solving statistical problems by any solutions while still paying attention to the cognitive style of students.
\end{abstract}

Keywords : Statistical thinking profile, problem solving, Field Independent, Field Dependent

\section{Abstrak}

Berpikir statistik adálah aktivitas mental yang terjadi dari prosés mengidentifikasi informasi statistik hingga proses pengambilan keputusan atau penarikan kesimpulan yang saling berhubungan. Salah satu yang dapat mempengaruhi profil berpikir statistik índividu adalah gaya kognitif. Tujuan penelitian ini adalah untuk mendeskripsikan profil berpikir statistik siswa SMA Field Independent dan Field Dependent dalam memecahkan masalah. Penelitian ini merupakan penelitian deskriptif dengan pendekatan kualitatif. Instrumen penelitian ini adalah peneliti sebagai instrumen utama dan tés gaya kognitif, tes kemampuan matematika, tes statistik, serta pedoman wawancara sebagai instrumén pendukung. Subjek penelitian yaitu satu siswa $F I$ dan satu siswa $F D$ dẹngan tingkat kemampuan matematika tinggi yang setara. Hasil penelitian ini menunjukkan perbedaan profil berpikir statistik siswa $F I$ dan $F D$. Pada aktivitas mengevaluasi keefektifan tampilan data, siswa $F I$ dapat memberikan argumennya secara analitis mengenai penyajian tampilan data yang lebih efektif digunakan dan siswa $F D$ memberikan jawaban untuk penyajian tampilan data yang efektif berdasarkan yang terlihat dari soal. Pada aktivitas memaparkan hasil penyelesaian dari permasalahan yang tersedia dan membuat kesimpulan dari hasil yang telah diperoleh, siswa $F I$ memaparkan penyelesaiannya dengan lebih rinci disertai dengan argumennya juga memberikan kesimpulan yang dihubungkan dengan permasalahan yang ada dan siswa $F D$ memaparkan penyelesaian secara singkat dan memberikan kesimpulan secara umum dan belum dihubungkan dengan permasalahan yang ada. Karena perbedaan kemampuan statistika yang dimiliki kedua subjek, sebaiknya guru memperhatikan konsep statistika siswa dan melatih siswa dalam memecahkan masalah statistika dengan beberapa penyelesaian dengan tetap memperhatikan gaya kognitif siswa.

Kata Kunci : Profil berpikir statistik, pemecahan masalah, Field Independent, Field Dependent 


\section{INTRODUCTION}

Many problems in daily life that the information can not be obtained without collecting and processing data from a situation. For example determining the number of victims of traffic accidents from police station in the past five months, the data obtained contains varying figures on the number of victims who suffered minor injuries, serious injuries, and death. If we want to know whether the number of accident victims each month tends to go up or down then we can't rely on experience to find out. The data obtained needs to be processed, so as to produce a conclusion that can be used. Because of that, we need a knowledge related to data processing called statistics.

Statistics is a way to add credibility to an argument or suggestion from a practical problem involving data, so a mental activity is needed that is thinking (Ben-Zvi and Garfield, in Wild 2005). Thinking to get conclusions from problems involving data including statistical thinking. There are 4 statistical thinking processes, abbreviated DORA, namely Describing Data Displays (D), Organizing and Reducing Data (O), Representing Data (R), and Analyzing and Interpreting Data (A) (Shaughnessy et all, in Martadiputra 2010). Researchers define statistical thinking as a mental activity that occurs from the process of identifying statistical information to the process of making decisions or drawing conclusions that are interconnected. In terms of statistical thinking. Akbar and Tsoraya (2013) in their research produced an average test of students' statistical thinking abilities of 65.29 and were classified as sufficient criteria. Besides that, Yusfita Yusuf (2017) in her research shows that the statistical skills of students at one of the universities in Sumedang also have low and sufficient statistical skills. It can be interpreted that the Indonesian people have not succeeded in applying statistics to solve complex problems in everyday life, but only utilize statistics in a simple way. Therefore, statistical understanding needs to be given to the community starting from elementary school and strengthening to junior high and senior high school levels.

To encourage developing students 'statistical thinking, the teacher should also adjust to the cognitive style of students, because the cognitive style of each student is different and can affect students' way of thinking. According to Rufi'i (2011) one of the characteristics of students that is important to be known and considered by teachers is cognitive style. Cognitive style is a part of learning style that describes the habit of behaving permanently in a person in receiving, thinking, solving problems, and recalling information (Keefe, in Darmono 2012). So cognitive style is one of the factors that can distinguish the way of thinking of an individual, including one of them is statistical thinking. Because thinking is a mental activity, the psychological condition of an individual can also affect the individual's thought process itself.

Cognitive style based on psychological aspects is divided into two namely Field Independent and Field Dependent. The fundamental difference between the two cognitive styles is in how to see a problem. Based on several studies in the field of psychology, it was found that individuals with Independent Field cognitive style tends to be more analytical in seeing a problem than Field Dependent cognitive style individuals. The characteristics of the Field Independent subject are as follows; need help understanding social science, need to be taught how to use context in understanding information, less influenced by criticism, easy to learn unstructured materials, tend to have their own goals and reinforcement, can analyze a situation and be able to rearrange it, and better able to solve problems without being guided (Woolfolk, in Darmono 2012). While the Field Dependent subject is as follows; easier to learn social science, more easily influenced by criticism, have good memories for social information, difficult to learn unstructured materials, need to be taught ways to use memory aids, tend to accept lessons that have been arranged and are unable rearrange them, and need to be taught how to solve problems (Woolfolk, in Darmono 2012). The basic characteristics of the two cognitive styles are very suitable to be applied in research involving thinking processes in solving mathematical problems. Because the subject fi and fd have different characteristics and some aspects that influence the thinking process are cognitive style and psychological aspects, it is necessary to know the statistical thinking profile for subjects with different cognitive styles, one of which is seen from the psychological aspects of fi and fd. This study is relevant to a study entitled "Statistical Thinking Profile of Junior High School Students in Learning Style" which aims to describe the profile of statistical thinking based on learning styles. That research has the same methodology as this research. Both of them 
are qualitative research on the profile of statistical thinking, only the difference between the two studies is the subject and research review. That study uses the subject of junior high school students and in terms of learning styles, namely auditory, visual, and kinesthetic learning styles, while this study uses the subject of senior high school students and in terms of cognitive style namely Field Independent and Field Dependent.

Based on the description above, the purpose of this study is to describe the profile of senior high school students' statistical thinking in solving problems in terms of differences in cognitive styles Field Independent and Field Dependent.

\section{METHOD}

This study aims to describe the statistical thinking profile of Field Independent and Field Dependent high school students in solving problems. B Based on the, research objectives, this research is a type of descriptive research with a qualitative approach. This study uses two types of instruments, namely the main instrument is the researcher and the supporting instruments that include cognitive style tests (Group Embedded Figures Test), mathematics ability tests, statistical problem solving tests, and interview guidelines. The subjects of this study were two high school students with high levels of mathematical ability with cognitive style Fiêld Independent and Field Dependent. How to choose these two subjects is based on the results of cognitive style tésts (Group Embedded Figures Test) and mathemátics ability tests. Cognitive style tests (GEFT) are given to a class of senior high school students together with ac math ability test, then look for students with a Field Independent and Field Dependent cognitive style éach one with a high level of mathematical ability. To determine the cognitive style that students have is to look at students' correct answers in working on GEFT that is from 25 questions if students answer correctly as many as 11 or fewer then including Field Dependent and if students answer correctly 12 or more then including Field Independent. While the results of high mathematical ability can be seen from the results of mathematics ability tests with mathematical ability test results 80 and above. Aside from being based on mathematics ability test scores, it is also based on recommendations from math teachers in the class. The data of this study were obtained from the results of statistical problem solving tests and interview results. The statistical problem solving test is carried out by the chosen subject and then interviews are conducted on the subject. the purpose of this interview is to dig deeper information that has not been conveyed in writing on the results of the statistical thinking test.

Data analysis in this study was divided into four, namely data analysis of cognitive style test results (Group Embedded Figures Test), data analysis of mathematical ability test results, data analysis of statistical problem solving test results, and data analysis of interview results. Data analysis of cognitive style test results (GEFT) is done by means of students grouped into two categories based on the results of correct answers of 25 GEFT questions done by students, namely Independent Fields, students who answer correctly as many as 10 to 25 , and Field Dependet, students who answer correctly 0 to 9 . The grouping of students in the cognitive style of Field Independent and Field Dependents is based on theory (Brenner, in Jamaluddin 2015). Data analysis of mathemáticál ability test résults is done by looking at the scores obtained by these students also with consideration of the daily value obtained from the mathematices teacher in the class. Data analysis of statistical problem solving test results based on statistical thinking indicators that have been adapted from Langrall, Cynthia Wrand Mooney, Edward S (2002).

Table 1. Statistical Thinking Indicator

\begin{tabular}{|c|c|}
\hline $\begin{array}{l}\text { Statistical thinking } \\
\text { process }\end{array}$ & $\begin{array}{c}\text { Activities that show } \\
\text { statistical thinking } \\
\text { processes }\end{array}$ \\
\hline $\begin{array}{l}\text { Describing data } \\
\text { displays }(\mathrm{A})\end{array}$ & 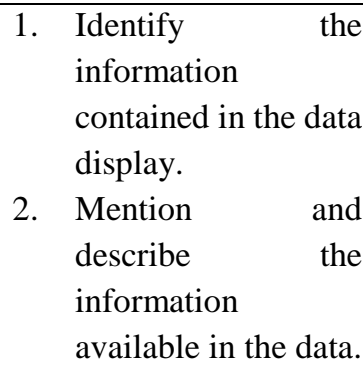 \\
\hline $\begin{array}{l}\text { Organizing and } \\
\text { reducing data (B) }\end{array}$ & $\begin{array}{l}\text { 1. Grouping data based } \\
\text { on information } \\
\text { already available. } \\
\text { 2. Determine the } \\
\text { centralization or } \\
\text { dissemination of }\end{array}$ \\
\hline
\end{tabular}




\begin{tabular}{|c|c|c|}
\hline & & $\begin{array}{l}\text { data suitable for use } \\
\text { based on } \\
\text { information already } \\
\text { available. }\end{array}$ \\
\hline $\begin{array}{l}\text { Representing data } \\
\text { (C) }\end{array}$ & 2. & $\begin{array}{l}\text { Creating a data } \\
\text { display based on } \\
\text { data information that } \\
\text { has been available. } \\
\text { Evaluate the } \\
\text { effectiveness of the } \\
\text { data display. }\end{array}$ \\
\hline $\begin{array}{l}\text { Analyzing and } \\
\text { Interpreting data } \\
\text { (D) }\end{array}$ & & $\begin{array}{l}\text { Make comparisons } \\
\text { between data. } \\
\text { Describe the results } \\
\text { of the resolution of } \\
\text { the available } \\
\text { problems. } \\
\text { Make conclusions } \\
\text { from the results } \\
\text { obtained. }\end{array}$ \\
\hline
\end{tabular}

Data analysis of the results of the interviews was carried out through three stages namely data reduction, data presentation, and drawing conclusions.

\section{RESULT AND DISCUSSION}

The statistical problem used in this study is as follows.

Describe the answers to the questions below clearly and in detail!

1. The diagram below shows the number of traffic accidents in an area.

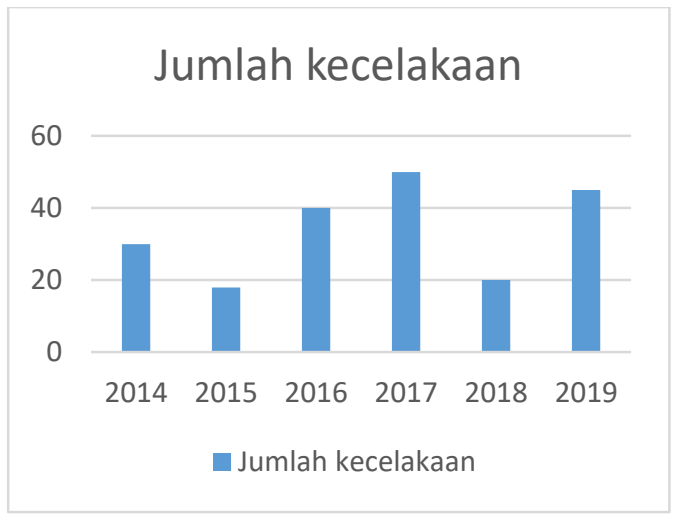

From that diagram

a. Show the data in the bar chart in the form of a pie chart!

b. What is the best measure of concentration or data dissemination used to see the bar diagram image? Explain your argument! c. What is the tendency to increase or decrease the number of accidents in the area in 20142019 ? Explain your argument!

2. A group of health teams conducted a survey of the spread of two diseases in the community in five villages this week. The survey results are presented in the table below.

Table 2. Diarrhea and Dengue Fever Survey

\begin{tabular}{|l|l|l|}
\multicolumn{1}{c|}{$\begin{array}{c}\text { Name of } \\
\text { Village }\end{array}$} & \multicolumn{2}{|c|}{ Types of diseases } \\
\cline { 2 - 3 } \multicolumn{1}{c|}{} & $\begin{array}{c}\text { Diarrhea } \\
\text { (people) }\end{array}$ & $\begin{array}{c}\text { Dengue } \\
\text { Fever } \\
\text { (people) }\end{array}$ \\
\hline Sukamaju & 3 & 15 \\
Sukaasih & 5 & 14 \\
Sukasenang & 52 & 16 \\
Sukakarya & 2 & 17 \\
Sukawangi & 10 & 13 \\
\hline
\end{tabular}

a. Show the data in the table in the form of pie charts!

b. Calculate the average value of the spread of each disease in the five villages!

c. Calculate the average deviation of the spread of each disease in the five villages!

d. What you can conclude from the results that you get?

Based on data analysis of statistical problem solving test results and interviews with subjects obtained a description of the statistical thinking profile of Field Independent and Field Dependent senior high school students in solving problems as follows.

\section{Statistical Thinking Profile of Field Independent Senior High School Student In Problem Solving}

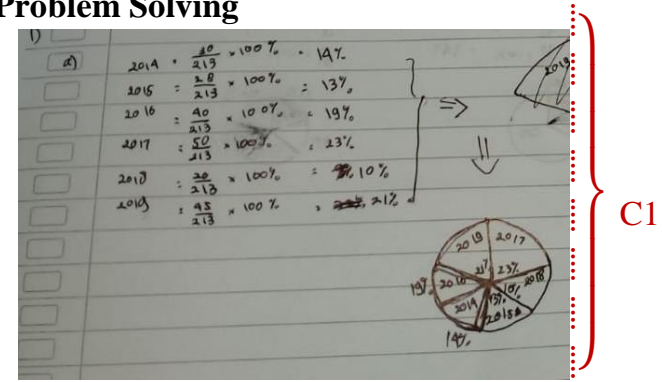

Figure 1. Answer of FI student number 1a

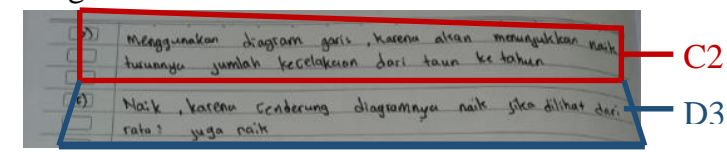

Figure 2. Answer of FI student number $1 \mathrm{~b}$ and $\mathrm{c}$ 
Based on the analysis of the results of the statistical thinking tests and interviews on item number 1, FI students were able to identify the information available in item number 1 well. FI students are able to recite what information is in question number 1 with their own language. The first thing a FI student does is read the data contained in a bar chart. Then write down the number of accidents each year as a form of information obtained from the questions. These activities include to the statistical thinking process in the section describing data displays. Furthermore, FI students are able to classify the difference each year between up and down. This activity enters the statistical thinking process in the part of organizing and reducing data. Furthermore FI students use averages to determine the up or down tendencies that occur in the data. This activity is also included in the process of statistical thinking in the section on organizing and reducing data.

Next in section 1a, students are asked to show the data in the form of pie charts. From this question, FI students first calculate the percent form by means of the number of accidents in that year divided by the number of accidents during the six years then multiplied by the full percentage of $100 \%$. After the six years the percentage is calculated, the FI student draws a circle diagram showing each part of the year and the percentage. These activities enter into the statistical thinking procéss in the-section representing data. Furthermore, the FI students in number $1 \mathrm{~b}$ answered that in this problem it was more effective to use a line diagram because the ups and downs of the number of accidents every year would be seén more clearly. This activity is also included in the process of statistical thinking in the section representing data. In the last part of question number 1 , students are asked to determine the tendency to go up or down along with their arguments. FI students answered that in this problem the tendency to increase was because the average of the data listed at a glance seemed to rise because the amount of increase was more than the decrease. In addition, if the respective average increases and decreases are calculated, the average increase will be greater than the average decrease. Therefore, FI students concluded that the problem was more likely to increase. But the calculation of the average rise or fall has not been clearly explained by FI students. This activity enters the statistical thinking process in the section analyzing and interpreting data.

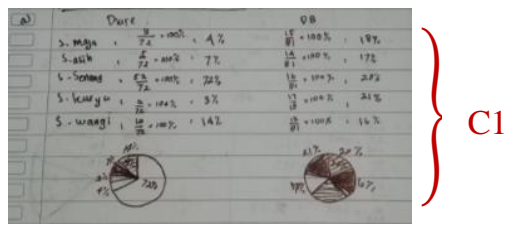

Figure 3. Answer of FI student number 2a

Based on the analysis of the results of the statistical thinking tests and interviews on item number 2, FI students were able to identify what information contained in item number 2 properly. FI students are also able to convey information that has been received using their own language. The first thing that was done by FI students in working on question number 2 was to look at the data contained in the table. Then FI students begin to work on question number 2 part a, the step used is to first determine the percentage of each village with each disease by the number of people affected-by the first disease in the first village divided by the number of people affected by the first disease the five villages are then multiplied by the full percentage of $100 \%$, this also applies to the calculation of the percentage of the second disease. After that, FI students begin drawing a pie chart and dividing the circle into each part of the village with the appropriate percentage for each disease. These activities are included in the statistical thinking process in the section representing data.

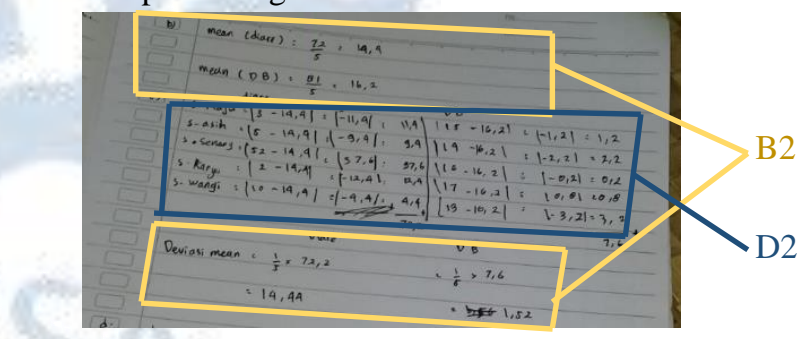

Figure 4. Answer of FI student number $2 \mathrm{~b}$ and $\mathrm{c}$

Next the FI students answered the questions in number $2 \mathrm{~b}$ by calculating the average by adding up all people affected by each disease from the five villages, then dividing by 5 which shows the number of villages used as the survey site. So get an average yield for each disease. FI students also answer the questions in number $2 \mathrm{c}$ by calculating the average deviation that is by adding up the absolute value of each data subtracted by the average that was previously calculated then divided by 5 namely the number of villages used as survey sites. That applies to each disease. So get the average deviation results for each disease. Activities 
undertaken by FI students in working on questions number $2 \mathrm{~b}$ and $\mathrm{c}$ enter into the process of statistical thinking on the part of organizing and reducing data.

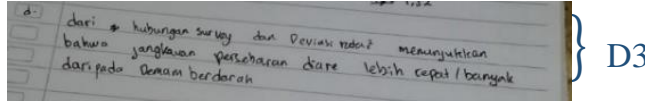

Figure 5. Answer of FI student number 2d

In problem number $2 \mathrm{~d}$, FI students concluded that the spread of diarrheal disease was faster than that of dengue fever because the average deviation of diarrhea was higher than the average deviation of dengue fever. This activity is included in the statistical thinking process in the section analyzing and interpreting data. Some characteristics possessed by Field Independent students in solving this problem are in accordance with some of the characteristics that have been mentioned by Woolfolk (in Darmono, 2012) that subjects with the cognitive style of Field Independent are easy to learn unstructured materials, can analyze a situation and are áble to rearrange them, and able to solve problems without being guided. This opinion is also in accordance with the results of a Darmono study (2012) that subjects with the cognitive style of Field Independent tend to be able to analyze and be more systematic in receiving information from the environment.

2. Statistical Thinking Profile of Field Dependent Senior High School Student In Problem Solving

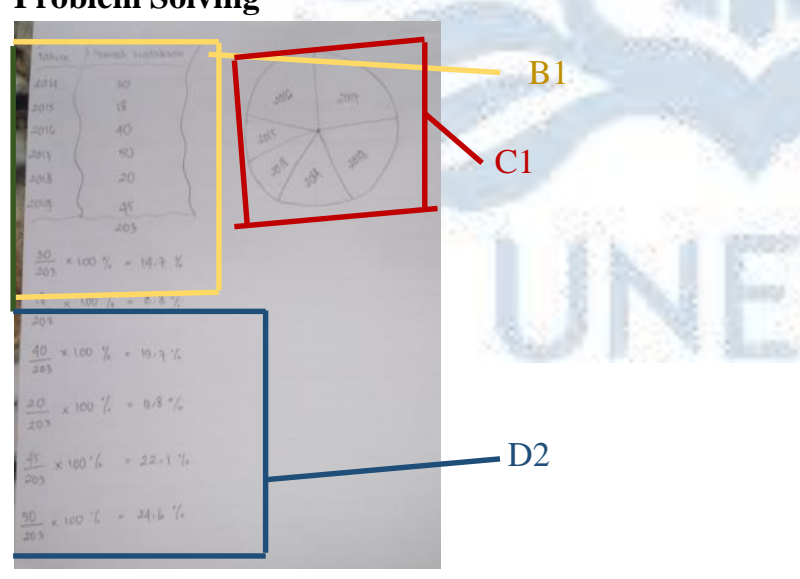

Figure 6. Answer of FD student number 1a

Based on the analysis of the results of the statistical thinking tests and interviews on item number 1, FD students were able to identify the information obtained from item number 1 quite well. FD students are also able to convey information that has been obtained in their own language. The initial step taken by the FD subject in answering question number 1 is to read the data then present the data in tabular form on the grounds that FD students will do more work if the data presentation is in tabular form than in a bar chart. These activities enter into the process of statistical thinking in the section describing the display data and representing data. Then the FD students determine the percentage of each year by the number of accidents each year divided by the number of accidents during the six years then multiplied by the full percentage of $100 \%$. After each year gets a percentage of each part, FD students draw a circle diagram and divide it according to the percentage of each year. This activity is included in the statistical thinking process in the section representing data.

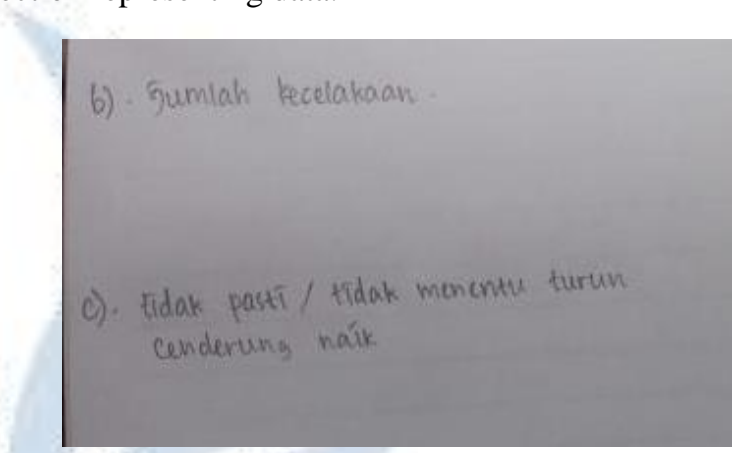

Figure 7. Answer of FD student number $2 \mathrm{~b}$ and $\mathrm{c}$

Next in number $1 \mathrm{~b}$, the FD student answers the number of accidents from the question of the form of presentation, the size of the convergence or dissemination of what data is appropriate from the data listed accompánied by an argument. When asked why answering so, FD students answered that FD students did not understañd the question. As for questions in number 1c, FD-students answer uncertain / uncertain downward tend to go up. FD students give reasons for their answers, because from the bar charts available in the problem, the number of accidents increases from time to time, also decreases from time to time. From the FD student's statement, the FD student did not meet the statistical thinking process in the part of organizing and reducing data and analyzing and interpreting the data. 


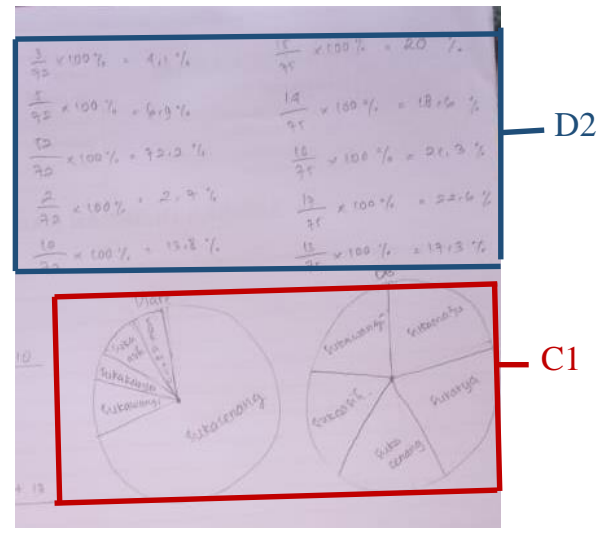

Figure 8. Answer of FD student number 2a

Based on the analysis of the results of statistical thinking tests and interviews, FD students are able to identify what information is listed in question number 2 properly. FD students are able to convey information previously obtained using their ${ }_{r}$ own language quite well. The first thing a FD student does in working on question number 2 is to look at the data presented in the form of a table listed in question number 2 . Then the FD student starts by working on question number $2 \mathrm{a}$, by first determining the percentage of each village for each village. diseases carried out by counting the number of people affected by the first disease in one village divided by the number of people affected by the first disease in five te villages. The number is then multiplied by the full perrcentage of $100 \%$. That also applies to the calculation of the percentage of parts for the second disease. After all the percentages are obtained, the FD student draws a pie chart and divides it according to the percentage that was previously calculated. This activity enters the státistical thinking process in the section representing data.

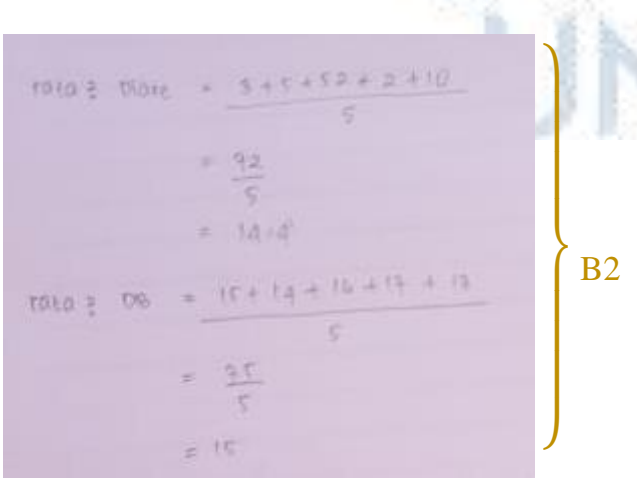

Figure 9. Answer of FD student number 2b

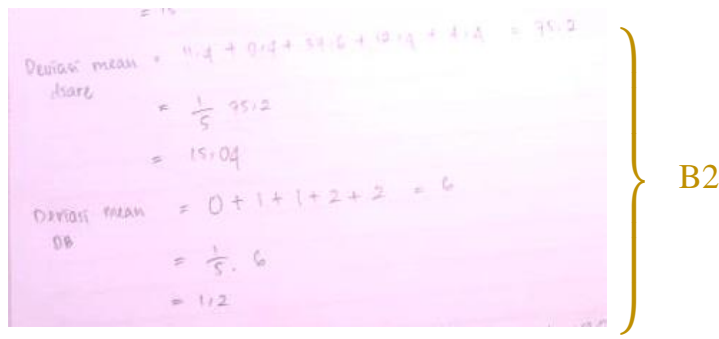

Figure 10. Answer of FD student number 2c

Next to questions number $2 \mathrm{~b}$ and $\mathrm{c}$, FD students answer by calculating the average and average deviation of each disease. But the explanation of the calculation is still not detailed. However, FD students can get appropriate answers and can explain in morę detail in interviews about the translation of the calculations.

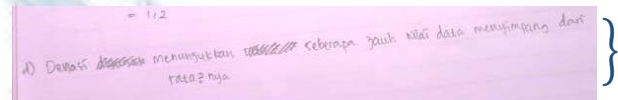

Figure 11. Answer of FD student number $2 \mathrm{~d}$

In question númber $2 \mathrm{~d}$, FD students generally concluded that the deviation indicates how far the value of the data deviates from the average. FD students have not been able to conclude specifically related to the problem.

Some characteristics possessed by Field Dependent students in solving this problem are in accordancer with some characteristics of Field

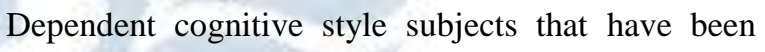
mentioned by Woolfolk (in Darmono, 2012) that Field Dependent subjects tend to accept structured lessons and need to be taught how to solve problems. In addition, according to Witkin, et al (in Rufi'i, 2011) that the characteristics of the Field Dependent tend to think globally and accept existing structures. So Darmono (2012) concluded that Field Dependent cognitive style subjects in thinking tend to be global (whole), so they are easy to follow and do not need analytical and systematic thinking.

In brief, the profile thinking of Field Independent and Field Dependent High School students in solving problems can be presented in the following table.

\section{CONCLUSION}

Based on the results of data analysis and discussion related to the results of the statistical thinking test can be described that the statistical thinking profile of 
senior high school students in solving problems in terms of cognitive style is as follows.

\section{Statistical Thinking Profile of Field Independent} Senior High School Student In Problem Solving

In the section describing the data display, the profile of statistical thinking achieved by students is to be able to identify the information contained in the data display in the problem and then the student can recount and describe the information available in the data in their own language. Furthermore, in the section on organizing and reducing data, the statistical thinking profile achieved by students is to be able to group data based on information already available on the problem and determine the form of data presentation, size of concentration or data dissemination, which is suitable for use on problems for which information is available. In the section representing data, the profile of statistical thinking achieved by students is to be able to make data , displays based on information already available and to evaluate the effectiveness of the data display used. Students can also determine the form of presentation of data display which is more effective to use along with the argument. In the section analyzing and interpreting data, the profile_of statistical thinking achieved by students is that they can explain the results of the resolution of the problems available in more detail and can make conclusions from the results obtained that are associafed with the problem displayed. Some characteristics possessed by Field Independent students in solving this problem are in accordance with some of the characteristics that have been mentioned by Woolfolk (in Darmono, 2012) that subjects with the cognitive style of Field Independent are easy to learn unstructured materials, can analyze a situation and are able to rearrange them, and able to solve problems without being guided. This opinion is also in accordance with the results of a Darmono study (2012) that subjects with the cognitive style of Field Independent tend to be able to analyze and be more systematic in receiving information from the environment.

\section{Statistical Thinking Profile Of Field Dependent Senior High School Student In Problem Solving} In the section describing the data display, the profile of statistical thinking achieved by students is to be able to identify the information contained in the data display and then students can re-mention the information available in the data using their own language. Furthermore, in the section on organizing and reducing data, the statistical thinking profile achieved by students is to be able to group data based on information that is already available, but it is still unable to determine the size of concentration or data distribution that is suitable for use based on available information. In the section on representing data, the profile of statistical thinking achieved by students is to be able to make data display based on information that has been available, but still cannot evaluate the effectiveness of the data display used. In the section analyzing and interpreting the data, the profile of students' statistical thinking that is achieved is that they can explain the results of the resolution of the problem but áre still lacking in detail. Students can also make conclusions from the results obtained, but still in the form of general conclusions and have not been able to relate to the available problems. Some charácteristiç possessed by Field Dependent students in solving this problem are in accordance with some characteristics of Field Dependent cognitive style subjects that have been mentioned by Woolfolk (in Darmono, 2012) that Field Dependent subjects tend to accept structured lessens and need to be taught how to solve próblems. In addition, according to Witkin, 'et al (in Rufi'i, 2011) that the characteristics of the Field Dependent tend to think globally and accept existing structures.'Sơ Dármono (2012) concluded that Field Dependent cognitive style subjects in thinking tend to be global (whole), so they are easy to follow and do not_need analytical and systematic thinking.

\section{REFFERENCES}

Akbar, Reza Oktiana dan Tsoraya, Rahmawati. 2013. Pengaruh Kemampuan Berpikir Statistik Terhadap Kreativitas Berpikir Siswa Dalam Matematika. Cirebon: IAIN Syekh Nurdjati.

As'ari, Abdur Rahman, dkk. 2018. Variasi Konstruk dalam Pembelajaran Matematika. Malang: Bintang Sejahtera.

Darmono, AL. 2012. Identifikasi Gaya Kognitif (Cognitive Style) Peserta Didik Dalam Belajar. Ngawi: STAI Ngawi.

Jamaluddin, Muhammad. 2015. Profil Berpikir Statistik Siswa Sekolah Menengah Pertama (SMP) ditinjau dari Gaya Belajar Program Studi S2 Pendidikan Matematika UNESA. Tesis tidak 
diterbitkan. Surabaya: PPs Universitas Negeri Surabaya.

Langrall, Cynthia W \& Mooney, Edward S. 2002. The Development of a Framework Characterizing Middle School Students Statistical Thinking. USA: Illinois State University.

Martadiputra, Bambang A. P. 2010. Kajian Tentang Kemampuan Melek Statistik ( Statistical Literacy), Penalaran Statistik (Statistical Reasoning), Dan Berpikir Statistik (Statistical Thinking) Guru SMP/SMA.Bandung: FMIPA UPI.
Rufi'i. 2011. Dampak Gaya Kognitif Terhadap Perolehan Belajar Konsep Statistika. Surabaya: Universitas PGRI Adi Buana Surabaya.

Wild, C., \& Pfannkuch, M. 2005. Towards an Understanding of Statitistical Thinking In D. BenZvi, \& J. Garfield, (Eds.), The Challenge of developing Statistical Literacy, reasoning, and thinking (pp. 17-46). Dordrecht, Netherlands : Kluwer Academic Publisher.

Yusuf, Yusfita. 2017. Kontruksi Penalaran Statistik Pada Statistika Penelitian. Sumedang: STKIP Sebelas April.

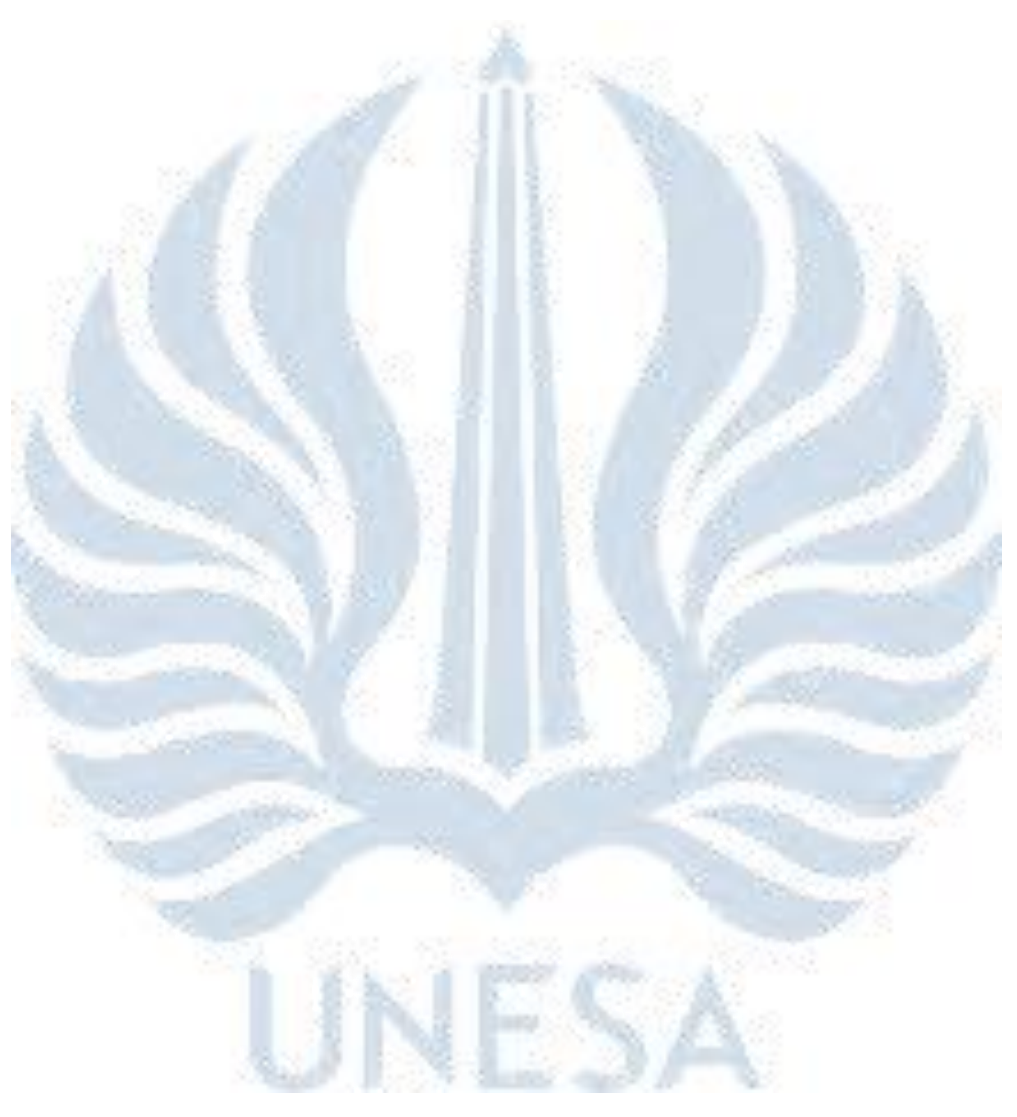

